\title{
7. Rights and obligations in the context of internships and traineeships: A German perspective Bernd Waas
}

\subsection{INTRODUCTION}

In 2005, the German weekly newspaper Die Zeit published an article entitled 'Generation Praktikum'. Part of the article read as follows:

In and of itself, internships are a good thing. In the past they were often called trial internships, because it was about smelling into a cement factory or an advertising agency to find out whether the job suits you or not. Today's interns have long since decided on a career. However, the more unemployed young academics there are, the more companies prefer to hire interns who do professional work for little money. Thus meanwhile between school and occupation lies a time of internships, which frequently lasts several years. ${ }^{1}$

Although reliable figures - especially reliable current figures - are lacking, there is still widespread unease about internships. For example, in a recent article on internships and related (labour) legal problems, the authors acknowledge the significance of internships, but add the following:

The other side of the coin is the increased number of cases of abuse, particularly in certain sectors, in which employers systematically and permanently fill regular jobs with exchangeable interns in order to save personnel costs and social security contributions. Since these jobs - regardless of their actual content - are often not paid or only paid at a low rate, especially after the end of training, internships have become an archetype of 'precarious employment' alongside voluntary and temporary work relationships. $^{2}$

Matthias Stolz, ‘Generation Praktikum’ Die Zeit (Hamburg, 31 March 2005).

2 Julia Burkard Pötter and Stephan Sura, 'Das Praktikum im neuen Gewand: Praxiseinblicke zwischen Mindestlohn und prekärem Beschäftigungsverhältnis’ (2015) 68 Neue Juristische Wochenschrift 517, 517. However, a study published in February 2020 shows that trainees are currently largely satisfied with their working conditions; 
In this chapter, I first describe what is meant by internships (and traineeships) in Germany and how these are distinguished from employment relationships in particular (section 7.2), before briefly discussing special types of internships (section 7.3). Next I identify which regulations are applicable to internships (section 7.4). Based on this, I discuss important aspects of traineeships (section 7.5) with a focus on the problem of ensuring adequate remuneration for trainees. The chapter ends with a short summary (section 7.6).

\subsection{TRAINEESHIPS, INTERNSHIPS AND SIMILAR RELATIONSHIPS}

Any, even moderately, profound examination begins with definitions. This is also the case with this survey. It is all the more important to spend a little time on definitions, as there are a large number of arrangements in Germany which have similarities with internships and traineeships. As a consequence, it is not uncommon in practice for delimitation problems to arise, and clear definitions can help to solve them.

\subsubsection{Vocational Training Relationships}

Vocational training in Germany is regulated by the Vocational Training Act (Berufsbildungsgesetz, BBiG). The law defines vocational training in principle as initial training following compulsory full-time schooling. However, it can also follow an initial vocational training. Basic knowledge, basic skills and behavioural patterns that are necessary for as many activities as possible must be conveyed in basic vocational training. This is generally actioned in a dual system, that is, training takes place in parallel in a company and at a vocational school; for some occupational fields, however, the first year of training can be designed as a purely school-based basic vocational training year. The vocational skills, knowledge and abilities required for an occupation are covered in that basic vocational training. Pursuant to BBiG section 4(2), vocational training must take place in an orderly training course in accordance with the training regulations. ${ }^{3}$

Of particular interest in this context is the vocational training relationship (Berufsausbildungsverhältnis). This relationship is based on a vocational training contract. Under BBiG section 10(1), anyone hiring people for voca-

see Nadine Bös, 'Generation Praktikum war gestern' Frankfurter Allgemeine Zeitung (Frankfurt am Main, 6 February 2020) 18.

3 See Monika Schlachter, 'Berufsbildungsgesetz' in Rudi Müller-Glöge, Ulrich Preis and Ingrid Schmidt (eds), Erfurter Kommentar zum Arbeitsrecht (21st edn, Beck 2021) s $1, \mathrm{n} 4$. 
tional training must conclude a vocational training contract with the trainees. Pursuant to BBiG section 10(2), the legal provisions and principles of law applicable to the employment contract shall apply to the contract, insofar as nothing to the contrary results from its nature and purpose and from the law itself. This means that the training relationship is in principle subject to the regulations applicable to the employment relationship. The aim is to protect trainees in the same manner as employees. Contractual agreements that deviate from this are not permitted (BBiG section 25).

That BBiG section 10(2) declares the legal provisions and principles of labour law are basically applicable to vocational training contracts does not mean that the vocational training contract is an employment contract. ${ }^{4}$ The purpose of the vocational training contract is clearly described in BBiG section 10(1). It is concluded 'for the vocational training' of another person, and not for the purpose of performing dependent work as in the case of an employment contract. This may not even be demanded, as BBiG section 14(3) expressly states. According to this provision, 'trainees may only be assigned tasks that serve the purpose of the training and are appropriate to their physical strength'. According to the Federal Labour Court:

Vocational training relationships and employment relationships are not generally to be equated, because both contractual relationships have different obligations. According to section 611 of the Civil Code $^{5}$ the content of an employment relationship is the performance of the contractually owed service against payment of a remuneration. On the other hand, the trainee is entitled to be trained, while the main obligation of the trainee according to BBG s 14 is to provide the trainee with the training required to reach the target level, the knowledge and skills required to achieve the training objective. In contrast to an employee, the trainee does not owe any work in return for payment of a wage, but has to register in accordance with BBG s 13 sentence 1 to endeavour to acquire the vocational capacity to act which is required to achieve the training objective. ${ }^{6}$

\subsubsection{Internships (Praktika)}

According to the understanding in Germany, an intern is a person who, on the basis of an internship contract, is in a temporary in-company training relationship in preparation for their main occupation, which is part of an orderly basic vocational training. The aim of the internship contract is not to

4 See eg Heinrick Kiel, Stefen Lunk and Hartmut Oetker, Münchener Handbuch zum Arbeitsrecht (4th edn, Beck 2018) para 147, n 32ff. See also Federal Labour Court, 21 September 2011, 7 AZR 375/10.

5 BGB s 611a only came into effect in 2014.

6 Federal Labour Court, 12 February 2015, 6 AZR 845/13. 
complete a specialist training course. The intern rather wants to gain practical knowledge and experience in a specific field of work, the existence of which they may have to prove at the start of further training or study. The internship is thus a target-orientated partial training in professional knowledge and skills perhaps prescribed to the intern by a school, a higher education institution at which they are studying, or a company. The main purpose of the internship contract, in any event, is the provision of training.

In order to distinguish vocational training from an internship, the Federal Labour Court stated:

Vocational training is intended to impart the ability to act in an orderly course of training. This is not the case for an internship. As a rule, an intern works temporarily in a company in order to acquire the practical knowledge and experience required to prepare for a profession. However, no systematic vocational training takes place. Nor are interns obliged to take part in vocational school lessons and examinations. ${ }^{7}$

In the underlying case, an intern had requested that periods of an internship be credited against the probationary period in a subsequent apprenticeship. The Court considered this request to be unfounded owing to the legal differences between a vocational training relationship and an internship.

The Minimum Wage Act (Mindestlohngesetz, MiLoG), enacted in 2014, provided a statutory definition of the term 'intern' for the first time. According to MiLoG section 22(3):

interns, irrespective of the designation of the legal relationship, are persons who, according to the actual form and execution of the contractual relationship, undergo a certain operational activity for a limited period of time in order to acquire practical knowledge and experience in preparation for a vocational activity, without this being vocational training within the meaning of the Vocational Training Act or comparable practical training.

This was intended to increase legal clarity. ${ }^{8}$ However, the definition does raise issues of delimitation. This applies in particular to the term 'comparable practical training'. In the legal literature it is argued that practical training is only comparable if: (1) there is a (far-reaching) industry-wide consensus that it is a prerequisite for entering the profession, (2) the content and structure of

7 Federal Labour Court, 19 November 2015, 6 AZR 844/14. See also Federal Labour Court, 13 March 2003, 6 AZR 564/01.

8 See German Parliament, Printing Matter 18/2010 (new) 26. It is based on recommendation no 2.3 of the EU Council of Ministers of 4 December 2013, No 3301, on a quality framework for internships. 
the training are well defined, and (3) it comes close to vocational training in duration, scope and intensity. ${ }^{9}$

\subsubsection{Traineeships (Volontariate)}

Internships must be distinguished from traineeships. The Federal Labour Court has defined traineeships as follows:

The traineeship can have a wide variety of forms according to the needs of the profession in question and its specific purpose. It differs from the vocational training relationship in that it is an additional training which is intended to deepen or in certain respects extend the existing training, from the employment relationship in that the trainee does not permanently perform work necessary for the company, is intended to replace a necessary worker and is remunerated for it, but rather that he becomes active in addition to the necessary workers for his training and further training. ${ }^{10}$

In contrast to an intern, a traineeship's practical learning phase is not part of a comprehensive training programme. For this reason, a traineeship is not a prerequisite for completing vocational training. Accordingly, becoming a trainee is a voluntary opportunity to gain an overview of a particular profession and beyond. ${ }^{11}$

The legal definition of an internship in MiLoG section 22(1)(3) helps only to a limited extent. The legislature itself considered that traineeships as a whole did not fall within the scope of the law. ${ }^{12}$ However, the term 'traineeship' is not clearly defined and is understood as a general term for a number of phenomena. After all, it is widely assumed that a 'comparable practical training' within the meaning of MiLoG section 22(1)(3) for an editor - depending on the concrete form - is a traineeship in the journalistic field. ${ }^{13}$ It is irrelevant that working as an editor does not necessarily require a traineeship. ${ }^{14}$

9 See Stefan Greiner, 'Mindestlohngesetz' in Christian Rolfs, Richard Giesen, Ralf Kreikebohm and Peter Udsching (eds), Beck-OK Arbeitsrecht (59th edn, Beck 2021) s 22, n 15.

10 Federal Labour Court, 21 December 1954, 2 AZR 76/53.

See Friedrich Schade, Praktikumsrecht (Kohlhammer 2011) 5.

See German Parliament, Printing Matter 18/2010 (new), 26.

See ibid.

14 See Greiner (n 9) s 22, n 16 for further references. 


\subsection{DIFFERENT TYPES OF INTERNSHIPS}

\subsubsection{Traineeships for Pupils Related to School Education}

In Germany, every pupil has to complete a pupil (company) internship during their time at school. The details are regulated by the individual states on the basis of decrees and guidelines. The internship is intended to give pupils the opportunity to gain an impression of working life. A pupil internship can be an individual internship, an internship of a group of students or an internship which includes all students in a class. The duration of the internship varies depending on the type of internship.

The Federal Labour Court has ruled that the BBiG, which grants trainees special protection, is not applicable if the internship is an integral part of school education. This is because a pupil internship does not establish a training relationship within the meaning of the BBiG. ${ }^{15}$ This type of internship is a school event that takes place in a company. The teacher is responsible for its implementation. There is often no contractual relationship between the pupil and the company. ${ }^{16}$

\subsubsection{Mandatory Student Internships Related to Studies}

In many cases, faculties of higher education institutions stipulate a mandatory internship during a course of study as a prerequisite for successful completion of the studies. At most universities, at least two internships are prescribed in the study regulations of individual departments. According to the Federal Labour Court, these internships do not qualify as vocational training relationships either. The Court's reasoning is that the BBiG does not regulate and cannot regulate vocational training to the extent that it is subject to the legislative competence of the Länder (states) guaranteed under constitutional law. ${ }^{17}$ Accordingly, there is no vocational training relationship within the meaning of the $\mathrm{BBiG}$ if the training in question is part of university training. Instead, these internships are subject exclusively to the provisions of state law for universities and universities of applied sciences. ${ }^{18}$

See eg Federal Labour Court, 19 June 1974, 4 AZR 436/73.

16 See Werner Scherer, 'Verträge mit Praktikanten' [1986] Neue Zeitschrift für Arbeitsrecht 280, 284.

17 German Constitution arts 30, 70.

18 See Federal Labour Court, 19 June 1974, 4 AZR 436/73. 


\subsubsection{Voluntary Internships}

Different rules from those applicable to compulsory internships apply to internships which are entered into on a voluntary basis. These internships are not uncommon, especially among students, since they can increase the chances of direct entry to a career after successful completion of studies. Although the focus of a voluntary student internship is on in-company training and learning knowledge, skills and abilities, these internships do not qualify as vocational training within the meaning of the BBiG. However, this type of internship does qualify as an 'other contractual relationship' under BBiG section 26, which results in the application, in principle, of the legal provisions and principles applicable to the employment contract under section 10(2). This means that the intern who completes their internship during their studies is thus simultaneously in two legal relationships: on the one hand, as a student in a public law relationship with the university ${ }^{19}$ and, on the other, as an intern in a private law training relationship with the trainer. The two legal relationships complement each other without overlapping.

\subsection{APPLICABLE PROVISIONS}

As internships aim at acquiring 'practical knowledge and experience in preparation for a vocational activity', it comes as no surprise that, in principle, the BBiG applies to them; this means that, owing to BBiG section 10(2) mentioned previously, labour law is applicable, in principle. Moreover, in practice, internships may sometimes be employment relationships in disguise, in which labour case law applies.

\subsubsection{Applicability of Rules on Vocational Training}

According to BBiG section 26, 'unless an employment relationship has been agreed', most of the provisions of the $\mathrm{Act}^{20}$ apply to 'persons hired to acquire professional skills, knowledge, abilities or professional experience, other than vocational training'. This means that if the purpose of the contract is to provide training, most of the rules in the BBiG apply, ${ }^{21}$ even if the relationship does

19 This applies if the university is a public institution, as is usually the case in Germany.

20 These concern the establishment of the training relationship, duties of the trainers and duties of the trainees, remuneration, and commencement and termination of the training relationship.

21 Section 26 contains three modifications of the applicable provisions of the law. In particular, the statutory probationary period of a maximum of four months (BBiG s 20(2)) can be contractually shortened. 
not qualify as a vocational training relationship. According to case law, these 'other contractual relationships' are legal relationships in which knowledge or skills are imparted for the first time, ${ }^{22}$ that is, generally the training of interns and trainees. ${ }^{23}$

As already mentioned, however, pursuant to BBiG section 10(2), the legal provisions and principles applicable to the employment contract apply to the contract, ${ }^{24}$ 'insofar as nothing to the contrary results from its nature and purpose and from this Act'. This means that labour law regulations apply to internships to a large extent.

\subsubsection{Application of Labour Law as a Result of a Reclassification of the Internship}

Apart from that, labour law comprehensively applies when the participants have apparently only agreed to an internship in order to avoid the application of labour law. ${ }^{25}$ This is then reclassified into an employment relationship by the courts. In this respect, however, it is necessary to go a little further.

For decades there was no legal definition of the contract of employment in Germany. This only changed with the insertion of section 611a into the Civil Code (Bürgerliches Gesetzbuch, BGB). The provision has been in force since 1 April 2017. Section 611a(1) sentence 1 of BGB reads as follows: 'The contract of employment obliges the employee to perform work in the service of another person, in accordance with instructions and in the personal capacity of the employee.' In addition to the legal definition of the employment contract, other elements of the provision are of interest. According to BGB section $611 \mathrm{a}(1)$ sentence 5 , an overall assessment of all circumstances must be made in order to determine whether an employment contract exists. Moreover, BGB section $611 \mathrm{a}(1)$ sentence 6 stipulates that the designation in the contract is irrelevant if the execution of the contractual relationship shows that it is an employment relationship. That is, it does not depend on how the parties describe the contractual relationship, but on how the legal relationship

\footnotetext{
22 Federal Labour Court, 12 February 2013, 3 AZR 120/11.

23 Federal Labour Court, 19 June 1974, 4 AZR 43/73.

24 It should be noted that some special regulations apply in light of the peculiarities of the vocational training relationship. For instance, termination of the vocational training relationship by giving notice is permitted only to a limited extent. In addition, modifications of the relevant legal provisions and principles of labour law may be necessary so that they are applicable to vocational training contracts. See eg Federal Labour Court, 12 February 2015, 6 AZR 845/13, n 41.

${ }^{25}$ See also Martin Maties, 'Generation Praktikum - Praktika, Einfühlungsverhältnisse und ähnliche als umgangene Arbeitsverhältnisse?’ [2007] Recht der Arbeit 135.
} 
is classified objectively according to its business content. If the contract is executed differently from that which was expressly agreed, then the execution is decisive. This is because the practical application allows conclusions to be drawn about which rights and obligations the parties actually assumed. This means that, if there is no real internship, interns can be classified as employees.

An employment relationship is distinguished from an internship on the basis of whether the training and learning purpose is in the foreground. If there is a comprehensive performance obligation with the typical elements of an employment relationship, the underlying relationship is a sham internship and thus a genuine employment relationship. Among the criteria to be applied are the duration and type of activity, who is responsible for the result of the work, performance of overtime, rights of instruction vis-à-vis other trainees, extension of the trainee contract, and permanent filling of a trainee position. ${ }^{26}$

\subsection{CONTRACT, RIGHTS AND DUTIES}

\subsubsection{Contractual Issues}

Similar to any other contract under private law, an internship is based on a legal agreement between the contracting parties or, more precisely, an offer by one party and an acceptance by the other. The general requirements for an effective contract apply.

No particular form is required for the conclusion of an internship contract. However, there is an obligation to provide trainees with a written statement regarding their essential contractual conditions. According to the Act on Notification of Conditions Governing an Employment Relationship (Nachweisgesetz) section 2(1a)(1), 'anyone hiring a trainee must immediately after conclusion of the internship contract, at the latest before commencement of the trainee's work, set down the essential contractual conditions in writing, sign the transcript and hand it over to the intern' ${ }^{27}$

It should be noted that internship contracts are subject to judicial review if they constitute general terms and conditions. Thus, BGB section 307 is applicable among other things. According to this provision, terms of the contract are invalid if they unreasonably disadvantage a party to the contract contrary to the requirements of good faith, whereby unreasonable disadvantage may also result if the provision is not clear and understandable (BGB section 307(1)). In case of doubt, an unreasonable disadvantage is presumed to exist if a provision

26 Burkard Pötter and Sura (n 2). See also section 7.5.3 in this chapter.

27 Ulrich Preis, 'Nachweisgesetz' in Rudi Müller-Glöge, Ulrich Preis and Ingrid Schmidt (eds), Erfurter Kommentar zum Arbeitsrecht (21st edn, Beck 2021) s 2, n 27a. 
'cannot be reconciled with the fundamental ideas of the statutory regulation from which the deviation is made', or if a provision 'restricts essential rights or obligations arising from the nature of the contract to such an extent that the achievement of the purpose of the contract is endangered' (BGB section $307(2))$.

\subsubsection{Duties of the Intern}

The main duty of the intern can be derived from the legal definition of the trainee in MiLoG section 23. According to this definition, a trainee is someone who 'undergoes a certain operational activity ... in order to acquire practical knowledge and experience in preparation for a vocational activity'. This means that trainees are obliged to perform activities corresponding to their counterparts. Generally, the provisions of labour law, including working time law, apply.

In addition to the main obligation, there are also secondary obligations of the intern. These have their basis in BGB section 241(2), which is generally applicable to contractual relationships. Pursuant to section 241(2), 'an obligation may also, depending on its contents, oblige each party to take account of the rights, legal interests and other interests of the other party'.

\subsubsection{Duties of the company}

\subsubsection{General questions}

For a company, an internship gives rise to two main obligations. First, there is an obligation to provide training and employment. This obliges the company to employ the trainee in real terms and to train them in order to enable them to acquire the corresponding vocational skills, knowledge, abilities and professional experience. Second, there is an obligation to remunerate the intern for their work.

In addition to the main duties, companies have secondary duties. In particular, the intern is subject to protective duties. These are partly specified in the Act on Occupational Safety and Health (Arbeitsschutzgesetz, ArbSchG), section 1(1) sentence 1 of which seeks to ensure and improve the safety and health protection of employees at work through occupational health and safety measures. According to ArbSchG section 3(1), the employer is obliged to adopt the necessary occupational health and safety measures, taking into account the circumstances affecting the safety and health of employees at work. In addition, it must review the effectiveness of the measures taken and, if necessary, adapt them to the changed circumstances. All this also applies to internship providers. 
One of the biggest challenges, indeed probably the biggest, is to ensure that interns receive fair pay. To tackle this problem, courts and legislators have taken different approaches.

\subsubsection{Invalidity of the agreed remuneration and presumption of reasonable remuneration}

According to BGB section 612(1), remuneration is deemed to be silently agreed upon if the service can only be expected to be provided for remuneration under the circumstances. The purpose of this provision is to ensure that each service of monetary value leads to a corresponding right to remuneration. ${ }^{28}$ This also applies to interns. Accordingly, the Federal Labour Court decided that an intern who performs services of a higher value than those which they were required to perform according to the internship contract can demand remuneration corresponding to the higher value of the service. ${ }^{29}$

In principle, BGB section 612(1) applies if an agreement about the remuneration of the promised services is missing or the agreement about the gratuitousness of the services to be provided is null and void owing to immorality (BGB section 138). ${ }^{30}$ In the Court's view, if the parties agreed to complete an unpaid internship in a legally unobjectionable manner, it is still possible, in applying section 612(1), that there is an obligation to pay remuneration for certain services. The Federal Labour Court has explicitly stated in this respect:

According to the settled case law of the Court, the provision therefore applies (mutatis mutandis) if, for example, higher-quality services are provided beyond the scope of an employment contract at the instigation of the employer or with his approval, for which there is no remuneration provision. In these cases, the contractual remuneration regulation only covers the services owed, the remuneration of the non-contractual, higher-value work is performed in accordance with section 612 . The same applies if a trainee performs services of higher value than those which he has to perform during the traineeship. ${ }^{31}$

As a result, in this case the Court ordered the defendant to pay remuneration of $€ 8000$, even though an unpaid internship had been agreed between the parties.

Federal Labour Court, 10 February 2015, 9 AZR 289/13.

Ibid.

30 With regard to the latter, see eg Federal Labour Court, 18 March 2014, 9 AZR $694 / 12$.

31 Federal Labour Court, 10 February 2015, 9 AZR 289/13, n 14. See also Federal Labour Court, 7 July 1993, 5 AZR 488/92. 


\subsubsection{Reclassification of an internship as an employment relationship}

Occasionally, the courts go one step further and ask whether an internship in reality should not be classified as an employment relationship.

An illustration of the problem is a case that was decided by the Regional Labour Court Berlin-Brandenburg. ${ }^{32}$ The plaintiff studied the subject 'fashion journalism' and applied for a position as an 'editorial intern' at a publishing house shortly before completing her studies. The participants concluded an 'internship contract'. The contract provided for the payment of a monthly remuneration of $€ 400$. The plaintiff filed a lawsuit claiming remuneration equal to an editor's wage less the internship remuneration paid. The Court began its reasoning with the statement that a plaintiff is required to present evidence when claiming that they worked under an employment relationship rather than a traineeship. However, the Court referred to the principles of a graded burden of demonstration and proof. According to those principles, the burden of presentation and proof is transferred to the defendant if objective circumstances exist which suggest the existence of an employment relationship.

Applying these principles, the Court then affirmed the existence of an employment relationship in the present case. First, it argued that the term 'internship contract' is not clear, since an 'internship' can be carried out both as an employment relationship and as a non-employment relationship. Persons termed 'interns' in the contract could therefore also be employees. In addition, the Court pointed out that the written contract contained 'typical employee obligations'. The plaintiff was obliged to work 'daily' and for 'at least' eight hours in the defendant's branch; to follow the defendant's instructions; and to prove possible incapacity for work by presenting a certificate of incapacity for work. Her duties were specifically described ('Supervision and implementation of editorial projects, research, development of topics'). 'Remuneration' was also agreed. The leave regulation was 'typical for employees' in the Court's view. The written contract also contained the defendant's training obligations. In the Court's opinion, however, these did not indicate the predominance of the training purpose. For example, the contract referred to a 'training plan'. However, this 'training plan' had not been attached to the contract. It was therefore, as the Court remarked, not even 'on paper'. A document which the defendant only submitted in the statement of grounds of appeal did not meet the requirements for a 'training plan'. In the Court's view, a training plan must determine 'which learning steps are to be taught in which time through training, by whom, with which methods, in which contexts and at which workplace' ${ }^{33}$ The intended duration of the contract also indicated an employment

32 State Labour Court Berlin-Brandenburg, 20 May 2016, 6 Sa 1787/15.

$33 \quad$ Ibid n 55. 
relationship. According to both the case law and the definition in MiLoG section 22(1)(2), an internship is 'temporary'. However, a one-year full-time internship for a graduate of fashion journalism at a publishing house was no longer 'temporary'. Accordingly, in that case the Court affirmed the existence of an employment relationship. It summarized its findings, abstractly, as follows: 'Internships of graduates of a relevant course of study who have already completed their studies and who only serve to enter the labour market, but who are predominantly associated with the usual work tasks of employees, are fictitious internships and employment relationships. ${ }^{34}$

As far as the amount of the remuneration demanded by the plaintiff was concerned, the Court relied on BGB section 138. ${ }^{35}$ According to section 138(1), 'a legal transaction which is contrary to public policy is void'. Under section $138(2)$,

in particular, a legal transaction is void by which a person, by exploiting the predicament, inexperience, lack of sound judgement or considerable weakness of will of another, causes himself or a third party, in exchange for an act of performance, to be promised or granted pecuniary advantages which are clearly disproportionate to the performance.

In accordance with the case law of the Federal Labour Court, the Court assumed that there is a 'clear disproportion' if the value of the benefit is (at least) double the value of the consideration. In addition to the objective criteria, the courts generally demand the existence of a 'reprehensible attitude' in order to apply section 138. In the present case, the Court stated, however, that a particularly gross disproportion between performance and consideration generally leads to the assumption of a reprehensible attitude on the part of the beneficiary. In this connection, the Court also dealt with the defendant's objection that these internships were extraordinarily widespread. The Court stated:

The alleged thousand-fold prevalence of internship relationships such as that of the plaintiff does not eliminate any reprehensible attitude of the defendants, but only makes them more common. The newspaper article 'Generation Praktikum' in 2005, the advancement of the term to 'Word of the Year 2006' and the associated socio-political discussion - ultimately culminating in $\S 22$ (1) sentence 2, 3 MiLoG 2014 - show that a reference to the customary form of corresponding contracts even for a contract in 2013/2014 is only an expression of a fictitious naivety. ${ }^{36}$

Ibid $n 43$.

See also State Labour Court Baden-Württemberg, 8 February 2008, 5 Sa 45/07.

36 State Labour Court Berlin-Brandenburg, 20 May 2016, 6 Sa 1787/15. 
Also, the Court did not accept that the defendant may have made it easier for the plaintiff to enter the profession by offering the plaintiff a bogus internship. This did not eliminate the accusation of a reprehensible attitude, either: 'The exploitation of a bad labour market situation for journalists does not entitle them to pay only about $13 \%$ of the usual remuneration. ${ }^{37}$

In conclusion, the Court stated:

The fact that the applicant did not claim a higher remuneration during the traineeship does not constitute a legitimate expectation on the part of the defendant, nor do particular circumstances render the applicant's conduct contrary to good faith. The defendant dictated the terms of the contract. As a newcomer to the profession, the plaintiff was in a predicament. It is typical of a sham internship that a trainee does not demand higher remuneration during the 'internship'. This is due to legal ignorance and/or - if with legal ignorance - in the hope that a formal employment relationship will be offered after the 'internship' or at least a good internship certificate will facilitate the further professional career. The defendant tried to take advantage of this. The defendant is therefore not worth protecting. ${ }^{38}$

The Court applied BGB section 612(1) and awarded the plaintiff the collectively agreed wage of $€ 3000$.

\subsubsection{Statutory minimum pay}

The legislature has also addressed the problem of inadequate remuneration of interns. The statutory minimum wage, which has been in force in Germany since 2014, not only applies to employees, but has also been extended to interns or, to be precise, to a certain circle of interns.

According to the Minimum Pay Act (Mindestlohngesetz) section 22(1)(1), the Act applies to employees. However, under section 26(1)(2) of the Act, interns within the meaning of the $\mathrm{BBiG}$ section 26 are regarded as employees within the meaning of the Act unless they

1. undertake an obligatory internship on the basis of a provision under school law, a training regulation, a provision under higher education law or within the framework of training at a legally regulated university of cooperative education, 2. complete an internship of up to three months as an orientation for vocational training or study, ${ }^{39} 3$. complete an internship of up to three months to accompany a vocational or higher education course, if they have not previously had such a traineeship relationship with the same trainer, or 4 . participate in an initial qualification in

\footnotetext{
37 Ibid $n 81$.

38 Ibid $n 88$.

39 According to Federal Labour Court, 30 January 2019, 5 AZR 556/17, interns are not entitled to the statutory minimum wage if they perform the internship for orientation purposes for vocational training or at the beginning of a course of study and the duration does not exceed three months.
} 
accordance with $\S 54 \mathrm{a}$ of the Third Book of the Social Code or in vocational training preparation in accordance with sections 68 to 70 of the Vocational Training Act.

According to section 22, the statutory minimum wage is thus generally extended to trainees. However, the legislature did not want to restrict the use of internships. Accordingly, four exceptions are provided to avoid undermining the willingness of companies to offer internships. The contractual partner of the trainee bears the burden of proof and presentation of evidence for the existence of such exceptional cases.

The extension of the minimum wage entitlement to trainees is controversial from a legal policy point of view. Moreover, constitutional concerns have been raised against the regulation in the labour law literature. It is asserted in this respect, among others, that the law violates article 3 of the Constitution, which guarantees equality before the law by equating (particular) traineeships with employment relationships for the purpose of the minimum wage. ${ }^{40}$ These concerns did not prevail, however. ${ }^{41}$ The prevailing opinion asserts instead that both the trainee and the employee perform instruction-dependent work. The training purpose and thus the undisputed distinguishing feature was an internal fact which is objectively difficult to prove and which in the past had led to considerable problems of presentation of evidence and proof to identify abusive fictitious internships. As a consequence, internships and employment relationships are so close that the legislature is entitled to treat them equally in certain respects. ${ }^{42}$

\subsubsection{Other obligations}

Other obligations on the company arise from labour laws which, as mentioned previously, in principle apply to internships as well.

The Continued Remuneration Act (Entgeltfortzahlungsgesetz) applies to employees and salaried employees as well as to those employed for vocational training. That is, via section $26, \mathrm{BBiG}$ section 10 (2) also applies to internships covered by the BBiG. This includes section 3(1) sentence 1 of the Act. According to this provision, an employee is entitled to continued payment of remuneration in the event of illness up to a duration of six weeks, if they are prevented from performing their work as a result of the illness, without any fault on their part.

40 See Christian Picker and Philipp Sausmikat, 'Ausnahmsweise Mindestlohn?' [2014] Neue Zeitschrift für Arbeitsrecht 942.

${ }_{41}$ See Greiner (n 9) s 22, n 6 ff.

${ }^{42}$ See Stefan Greiner, 'Die Praktikantenregelung in $\S 22$ MiLoG' [2016] Neue Zeitschrift für Arbeitsrecht 594, 596. 
As already mentioned, the Act on Occupational Safety and Health (Arbeitsschutzgesetz) also applies to interns. The Youth Employment Protection Act (Jugendarbeitsschutzgesetz), which contains regulations for the protection of minors, applies as well. Accordingly, the special working time regulations of this law are applicable.

Finally, pursuant to section 6(1) number 2 of the General Equal Treatment Act (Allgemeines Gleichbehandlungsgesetz), the Act also applies to 'those employed for their vocational training'. This term is used to make it clear that not only the training relationships subject to the $\mathrm{BBiG}$ are included, but also retrainees, volunteers, interns and so on who are hired 'outside an employment relationship in order to acquire vocational skills, knowledge or experience' (within the meaning of BBiG section 26). ${ }^{43}$

\subsubsection{Dismissal Protection}

For internships within the meaning of BBiG section 26, section 22 of the law will apply mutatis mutandis. Pursuant to BBiG section 22(1), the vocational training relationship may be terminated at any time without notice during the probationary period ${ }^{44}$ After the probationary period, the vocational training relationship may only be terminated: (1) for an important reason without observing a period of notice, or (2) by trainees with a period of notice of four weeks if they wish to give up vocational training or train for another occupation (BBiG section 22(2)). Notice of termination must be given in writing and, in the cases referred to in subsection 2, must state the reasons for the termination (BBiG section 22(3)). A termination for an important reason is invalid if the facts on which it is based have been known to the person entitled to the termination for longer than two weeks (section 22(4) sentence 1). ${ }^{45}$

It should also be noted that internships are necessarily fixed-term contracts. The rules on fixed-term employment contracts under the Part-Time and Fixed-Term Contracts Act (Teilzeit- und Befristungsgesetz) apply to them.

\subsubsection{Collective Bargaining}

Trade unions and employers or, much more frequently in Germany, employers' associations can conclude collective agreements for employees ${ }^{46}$ Pursuant

\footnotetext{
43 See Schlachter (n 3) s 6, n 2.

44 BBiG s 20(1) allows a probationary period of one month for an apprenticeship.

45 If a planned conciliation procedure is initiated before an out-of-court body, this period shall be suspended until its termination (BBiG s 22(4) sentence 2).

46 According to s 12a of the Act on Collective Agreements (Tarifvertragsgesetz), these agreements can also be concluded for quasi-employees (Arbeitnehmerähnliche).
} 
to $\mathrm{BBiG}$ section 10(2), this authority to conclude collective agreements also applies to trainees. ${ }^{47}$ For other non-employees, the bargaining parties have no legislative power. For example, they cannot specify a minimum remuneration for students in a study internship (even at a private university). ${ }^{48}$ Consequently, collective agreements may be applicable to traineeships. It should be noted that there are independent collective agreements for internships, for example, for interns in the public sector. ${ }^{49}$ The personal scope of the collective agreement is always decisive. Every individual collective agreement needs to be examined to determine whether it also covers apprenticeships, including internships. ${ }^{50}$

\subsection{SUMMARY}

In practice, internships (and traineeships) often cause difficulties in defining boundaries. In addition, different types of internships follow different rules. In principle, the regulations that apply to vocational training apply to internships. In this way, it is also possible to achieve a far-reaching applicability of labour law regulations, as these are also generally applicable to vocational training relationships. In addition, it should be noted that internships must be classified as employment relationships if they have only been completed as a pretence. This then leads to the full application of labour law and has the consequence, among others, that the employer of the intern is obliged to pay the remuneration which they owe to an employee, for example, on the basis of a collective agreement. Apart from all this, it should be noted that some years ago the legislature introduced a general statutory minimum wage, which also applies to a large extent to interns.

47 Trainees also enjoy the right to strike: see eg Federal Labour Court, 12 September 1984, 1 AZR 342/83.

48 See Peter Löwisch and Volker Rieble, Tarifvertragsgesetz (4th edn, Beck 2017) s 2, n 261 .

49 'Tarifvertrag für Praktikantinnen und Praktikanten - Öffentlicher Dienst' (Öffentlicher Dienst, 2 October 2018), https://www.oeffentlichen-dienst.de/ auszubildende/312-praktikanten/44-tarifvertrag-praktikant.html, accessed 30 March 2021.

50 See Schade (n 11) 97. 